\title{
Constraints in weed biological control: contrasting responses by implementing nations
}

\author{
M. Schwarzländer • V. C. Moran · S. Raghu
}

Received: 7 January 2018/ Accepted: 2 May 2018/Published online: 5 May 2018

(C) International Organization for Biological Control (IOBC) 2018

\begin{abstract}
The compilation of papers in this Special Issue (SI) derives from a Symposium at the 25th International Congress of Entomology, in 2016, entitled "Rise or demise? A global outlook on the future of classical biological weed control". In the SIopening-paper, a summary of the 5th edition of the world catalogue of weed biocontrol agents and their target weeds provides a comprehensive international perspective. Weed biocontrol implementation is beleaguered by perceptions of risk and restrictive regulatory procedures, notably in the USA, and less so in Canada. Thus, most of the papers in this SI comprise accounts of innovative responses to these challenges from scientists in the USA. Political and funding issues have inhibited weed biocontrol in Australia over the past decade, but there appears to be a gradual reversal of this trend in recent years. In
\end{abstract}

Handling Editor: Eric Wajnberg.

M. Schwarzländer

Department of Plant, Soil, and Entomological Sciences, University of Idaho, Moscow, ID 83844, USA

e-mail: markschw@uidaho.edu

V. C. Moran

Department of Biological Sciences, University of Cape Town, Rondebosch 7701, South Africa

e-mail: vincent.moran@uct.ac.za

S. Raghu $(\bowtie)$

CSIRO, GPO Box 2583, Brisbane, QLD 4001, Australia

e-mail: s.raghu@csiro.au contrast, in New Zealand and in South Africa, the practice is flourishing, and there are significant recent initiatives in Europe. Overall, the contributions in the SI suggest an optimistic prognosis for weed biological control.

Keywords World catalogue - Successes and failures · Non-target effects · Risk assessments · Hostspecificity $\cdot$ Community involvement

\section{Introduction}

Biological control of weeds, based on applications of ecological, evolutionary and experimental science, is a highly successful discipline with a rich history, going back over 115 years. It is a global practice: the development of every weed biological control organism, and its subsequent release in the country of introduction, requires collaborative research on at least two continents and typically includes the involvement of several countries. Weed biocontrol practitioners, comprising researchers, land managers and policy makers, constitute a community with a shared goal, namely the suppression of invasive alien plants in agriculture and in conservation areas, through the deployment of suitably-tested and environmentally safe (i.e. sufficiently host-specific), plant-feeding insects, mites and pathogens. 
A complete record of every deliberate instance of weed biocontrol, worldwide, up to December 2012 (see Table 1 in Winston et al. 2014; and updated at http://www.ibiocontrol.org/catalog/) has been compiled in the expansive 5th edition of 'Biological control of weeds-A world catalogue of agents and their target weeds'. This compilation records successes and failures, with accounts of the circumstances in each case, and a summary of the information by Schwarzländer et al. (2018) is the subject of the opening paper in this Special Issue of BioControl.

\section{Perceptions of risk in weed biological control}

Challenges to biological control generally, including biocontrol of insect pests (using mostly predators and parasitoids), and to weed biocontrol, were catalyzed by Howarth (1991) and led to a burgeoning literature debating the unanticipated and detrimental impacts of biological control agents on non-target organisms (e.g. Follett and Duan 2000; Wajnberg et al. 2001). Even though biocontrol of insect pests is clearly distinct from the biocontrol of weeds, operating on systems at different trophic levels, the two are often confounded, and flawed conclusions from invalidly-combined data sets have exacerbated the doubts that have arisen about the risks posed by weed biocontrol (Moran et al. 2005). Howarth noted “...the greater care and stricter guidelines required for the introduction of herbivores [as agents] ..." and Waage (2001) observed that "A tradition of safety [...] happened more rapidly with some kinds of biological control than with others. Specificity testing in weed biological control developed most rapidly, simply because of the more obvious threat which introduced plant feeding insects posed to crops, relative to the predators or parasitoids of insect pests." Thus, weed biological control practitioners have been acutely aware of non-target risks, and have undertaken research and implementation within carefully-appraised and steadily improved riskmanagement frameworks (Sheppard et al. 2003; van Driesche et al. 2010; Hill et al. 2013). As a result, almost all of the non-target effects observed have been predictable (Pemberton 2000), and after at least 1555 deliberate releases, globally, of 468 species of weed biocontrol agents (Schwarzländer et al. 2018), detrimental outcomes have been rare (Suckling and Sforza 2014).
Nonetheless, no enterprise is risk-free and some releases of weed biocontrol agents have been made which were unwise. In particular, two cases have gained notoriety: the cactus moth Cactoblastis cactorum (Berg) (Pyralidae) was released in the Caribbean Islands in the late 1950s and, by 1989, it had spread, or been inadvertently imported, to the USA; and a thistleweevil, Rhinocyllus conicus (Frölich) (Curculionidae), that was released in Canada and the USA in the late 1960s. Both species are oligophagous and they now pose a threat to populations of some species of native cacti and thistles, respectively, in the USA. These cases have seriously damaged perceptions of weed-biocontrol safety, resulting in highly risk-averse regulatory structures that have slowed the development of weed biocontrol, worldwide (Sheppard et al. 2003), and contributed to declines in the numbers of scientists involved in this practice (Moran and Hoffmann 2015).

Weed biocontrol in the USA and Hawaii, and to a lesser extent in Canada, has been most profoundly and negatively affected by regulatory and political constraints. Since 2010, only nine weed biocontrol agent species have been released in the continental USA and Hawaii (compared to 59 in the decade from 1990 to 1999), seven species were released in Canada, and seven in Australia, 13 in New Zealand, and 24 in South Africa. Not a single new weed biocontrol agent species was approved for release in the USA or Hawaii between 2011 and 2015 (USDA 2017), and, for the first time, a year has passed (in 2017) with no petitions for release of weed biocontrol agents having been submitted to the relevant regulatory agencies in the USA.

It is in this overall context that a symposium entitled "Rise or demise? A global outlook on the future of classical biological weed control" was held at the 25th International Congress of Entomology in Orlando, Florida, USA from 25 to 30 September 2016. The ICE2016 symposium proceedings, and the sample of key papers arising from it that are presented in this Special Issue, reflect the varying responses of the major implementing nations to the challenges and circumstances facing the discipline. 


\section{Facing the challenges: responses of the main implementing nations}

Given the protracted problems facing weed biocontrol in the USA and Hawaii, especially, it is not surprising that the emphasis in this Special Issue is provided by authors from the USA writing on risk assessments, conflicts of interest and regulations, and on the considerable complications of dealing with agenthost-fidelity for taxa at sub-specific levels (Bean and Dudley 2018; Casagrande et al. 2018; Smith et al. 2018), and on innovations to expand host-specificity procedures, to help make them more definitive (Park et al. 2018; Blossey et al. 2018). Two papers in this Special Issue have wide applicability: Schaffner et al. (2018) review and assess the use of open-field testing in risk assessments, and Blossey et al. (2018) argue that the use of long-term, plant demographic data should be an essential practical and conceptual component in debates on host-specificity, risk assessments, and in the evaluation of weed biological control in management programs. Presenting a glimpse of the obverse of the coin, two further papers highlight successful contributions to weed biological control in the USA: Pitcairn (2018) summarizes the history of successes in California; and Weed et al. (2018) document contemporary progress with weed biocontrol in Idaho, through the engagement of 'citizenscientists' and the general community.

It is ironic that Australia who, in the 1920s, in their programs against invasive cacti, provided the most spectacularly successful and extensive weed biocontrol success ever recorded, have also seen sharp declines in support for weed biocontrol and in the rate of agent releases, over the past decade (Schwarzländer et al. 2018). Partly, at least, this has been the result of political and regulatory wariness based on the ambivalence of scientists globally about the non-target debate. Since about 2007, large, long-term, highly successful federally-funded programs in Australia have not been renewed and, consequently, personnel numbers were so drastically cut that adequate maintenance of research impetus and infrastructure (e.g. quarantine facilities) has been extremely difficult (Palmer et al. 2014). These restraining circumstances have been partly offset, since 2015, by significant new federal and state-level funding. Equally important, perhaps, is that regulators of biological control are now actively re-engaging with weed biocontrol scientists to ensure the sustainable use of this practice in weed management.

New Zealand, in contrast to the regressions in the USA, Hawaii, Canada and Australia, continues to set the standard for cooperative and effective weed biocontrol. Their research programs are still well funded from diversified private and government sources (Hayes et al. 2013) and, albeit not without administrative hurdles nor absolutely guaranteed, currently their research and implementation efforts are supported for periods of up to seven years. Two new quarantine facilities have recently been builtone for pathogens (Fowler SV, pers. comm.) and an impressive range of weeds has been targeted (Hayes et al. 2013), and reported in a series of high-quality publications. Recently their operations have expanded to include some Pacific countries. Crucially, since 1998, when other countries have been variously mired in regulatory strictures, New Zealand has been operating under regulatory processes that are "stable, effective and manageable" and are based on the foundational premise that "the benefits of introduction [of new organisms] must outweigh any risks ..." (Hill et al. 2013), and Paynter et al. (2018) elaborate on research initiatives in New Zealand aimed at making weed biocontrol even safer and more effective.

South Africa has also made considerable progress, driven by an imperative to accelerate the management and suppression of problematic plants. It seems that the damage wrought by alien invasive plants to the South African economy and to livelihoods is more evident and consequential than that in many other countries: agriculture, water supplies, and conservation programs have been severely impacted, all of which has been exacerbated by more frequent and more devastating wild fires. Consequently, politicians have strongly supported the notion advanced by scientists that long-term suppression of invasive alien plants will not be possible without the inclusion of biological control in management practices (Moran et al. 2005). This has meant that, since 1995, the government has generously supported weed biocontrol, although the inertia and convolutions of the regulatory processes slowed weed biocontrol efforts for several years. South Africa has five weed biocontrol facilities, with satellite mass-rearing stations, targeting a wide array of invasive terrestrial and aquatic weeds. Personnel numbers (researchers, support staff, and implementing officers) have increased 
significantly over the last two decades. Recently, new, expansive and excellent quarantine and mass-rearing facilities have been built, supplemented by upgrades to separate amenities to handle pathogens. In October 2017, a major university-based institute, the Centre for Biological Control, was officially inaugurated (Hill MP, pers. comm.) which, as Martin et al. (2018) describe, has a long-standing and strong commitment to involvement by the wider community via a suite of innovative school- and adult-outreach-programs and educational initiatives.

\section{Conclusions}

It is clear that the considerable constraints in the USA and Hawaii (and to a lesser extent, in Canada and Australia) over the last two decades have shed a pessimistic light on the entire practice of weed biocontrol worldwide. Our impression, however, is that a nadir has been reached and that the precedents of the highly successful programs in New Zealand and South Africa, and early signs of rejuvenation of the discipline in Australia, lead to optimism. This confidence is given considerable added weight by the recent, intentional implementation of weed biocontrol in England and Portugal (Shaw et al. 2018) —an involvement which took a decade to gain approval from the European Union authorities, but it is undoubtedly a major step forward. It is also most encouraging that Argentina and Brazil, that have long been crucially-important source nations for weed biocontrol agents, have now become the first countries in South America to commit to the implementation of weed biological control in their homelands (e.g. McKay et al. 2018).

In spite of the multifaceted challenges and constraints facing biological control, generally and globally (Barratt et al. 2018; Messing and Brodeur 2018), absolute necessity and pragmatism in the face of increasing threats from alien invasive plants will ensure the eventual renaissance of weed biocontrol as a practice. If the proceedings at the ICE2016 Symposium, and the publications in this Special Issue of BioControl serve to offer a balanced and optimistic prognosis and provide an added impetus for weed biocontrol, then all these initiatives will have been worthwhile.
Acknowledgements The papers in this Special Issue were delivered as presentations as part of a symposium entitled "Rise or demise? A global outlook on the future of classical biological weed control" at the 25th International Congress of Entomology in Orlando, Florida, USA from 25 to 30 September 2016.

\section{References}

Barratt BIP, Moran VC, Bigler F, van Lenteren JC (2018) The status of biological control and recommendations for improving uptake for the future. BioControl 63:155-167

Bean D, Dudley T (2018) A synoptic review of Tamarix biocontrol in North America: tracking success in the midst of controversy. BioControl. https://doi.org/10.1007/s10526018-9880-х

Blossey B, Dávalos A, Simmons W, Ding J (2018) A proposal to use plant demographic data to assess potential weed biological control agents' impacts on non-target plant populations. BioControl. https://doi.org/10.1007/s10526-0189886-4

Casagrande RA, Häfliger P, Hinz HL, Tewksbury L, Blossey B (2018) Grasses as appropriate targets in weed biocontrol: is the common reed, Phragmites australis, an anomaly? BioControl. https://doi.org/10.1007/s10526-018-9871-y

Follett PA, Duan JJ (2000) Nontarget effects of biological control. Kluwer, Boston

Hayes L, Fowler SV, Paynter Q, Groenteman R, Peterson P, Dodd S, Bellgard S (2013) Biocontrol of weeds: achievements to date and future outlook. In: Dymond JR (ed) Ecosystem services in New Zealand-conditions and trends. Manaaki Whenua Press, Lincoln, pp 375-385

Hill R, Campbell D, Hayes L, Corin S, Fowler S (2013) Why the New Zealand regulatory system for introducing new biological control agents works. In: Wu Y, Johnson T, Sing S, Raghu S, Wheeler G, Pratt P, Warner K, Center T, Goolsby J, Reardon R (eds) Proceedings of the XIII international symposium on biological control of weeds (2011). USDA Forest Service, Forest Health Enterprise Technology Team, Morgantown, pp 75-83

Howarth FG (1991) Environmental impacts of classical biological control. Annu Rev Entomol 36:485-509

Martin GD, Hill MP, Coetzee JA, Weaver KN, Hill JM (2018) Synergies between research organisations and the wider community in enhancing weed biological control in South Africa. BioControl. https://doi.org/10.1007/s10526-0179846-4

McKay F, Logarzo G, Natale E, Sosa A, Walsh GC, Pratt PD, Sodergren C (2018) Feasibility assessment for the classical biological control of Tamarix in Argentina. BioControl 63:169-184. https://doi.org/10.1007/s10526-017-9855-3

Messing R, Brodeur J (2018) Current challenges to the implementation of classical biological control. BioControl 63:1-9

Moran VC, Hoffmann JH (2015) The fourteen International Symposia on Biological Control of Weeds, 1969-2014: delegates, demographics and inferences from the debate on non-target effects. Biol Control 87:23-31 
Moran VC, Hoffmann JH, Zimmermann HG (2005) Biological control of invasive alien plants in South Africa: necessity, circumspection and success. Front Ecol Environ 3:77-83

Palmer WA, McLaren D, Sheppard AW (2014) Australia's present scientific capacity to progress the biological control of weeds. In: Impson FAC, Kleinjan CA, Hoffmann JH (eds) Proceedings of the XIV international symposium on biological control of weeds. Kruger National Park, Nelspruit, pp 183-186

Park I, Eigenbrode SD, Cook SP, Harmon BL, Hinz HL, Schaffner U, Schwarzländer M (2018) Examining olfactory and visual cues governing host-specificity of a weed biological control candidate species to refine pre-release risk assessment. BioControl. https://doi.org/10.1007/ s10526-018-9867-7

Paynter QE, Fowler SV, Groenteman R (2018) Making weed biological control predictable, safer and more effective: perspectives from New Zealand. BioControl. https://doi. org/10.1007/s10526-017-9837-5

Pemberton RW (2000) Predictable risk to native plants in weed biological control. Oecologia 125:489-494

Pitcairn M (2018) Weed biological control in California, USA: review of the past and prospects for the future. BioControl (in press)

Schaffner U, Smith L, Cristofaro M (2018) A review of openfield host range testing to evaluate non-target use by herbivorous biological control candidates. BioControl. https:// doi.org/10.1007/s10526-018-9875-7

Schwarzländer M, Hinz HL, Winston RL, Day MD (2018) Biological control of weeds: an analysis of introductions, rates of establishment and estimates of success, worldwide. BioControl (in press)

Shaw RH, Ellison CA, Marchante H, Pratt CF, Schaffner U, Sforza RFH, Deltoro V (2018) Weed biological control in the European Union: from serendipity to strategy. BioControl. https://doi.org/10.1007/s10526-017-9844-6

Sheppard AW, Hill R, DeClerck-Floate RA, McClay A, Olckers T, Quimby PC, Zimmerman HG (2003) A global review of risk-benefit-cost analysis for the introduction of classical biological control agents against weeds: a crisis in the making? BioControl News Inf 24:91N-108N

Smith L, Cristofaro M, Bon M-C, De Biase A, Petanović R, Vidović B (2018) The importance of cryptic species and subspecific populations in classic biological control of weeds: a North American perspective. BioControl. https:// doi.org/10.1007/s10526-017-9859-z

Suckling DM, Sforza RFH (2014) What magnitude are observed non-target impacts from weed biocontrol? PLoS ONE 9(1):e84847. https://doi.org/10.1371/journal.pone. 0084847

USDA (2017) https://www.aphis.usda.gov/aphis/ourfocus/ planthealth/import-information/permits/regulatedorganism-and-soil-permits/biological-control-organismpermits/sa_tag/ct_technical_advisory_group_biological_ control_agents_weeds van Driesche RG, Carruthers RI, Center T, Hoddle MS, HoughGoldstein J, Morin L, Smith L, Wagner DL, Blossey B, Brancatini V, Casagrande R, Causton CE, Coetzee JA, Cuda J, Ding J, Fowler SV, Frank JH, Fuester R, Goolsby J, Grodowitz M, Heard TA, Hill MP, Hoffmann JH, Huber J, Julien M, Kairo MTK, Kenis M, Mason P, Medal J, Messing R, Miller R, Moore A, Neuenschwander P, Newman R, Norambuena H, Palmer WA, Pemberton R, Panduro AP, Pratt PD, Rayamajhi M, Salom S, Sands D, Schooler S, Schwarzländer M, Sheppard A, Shaw R, Tipping PW, van Klinken RD (2010) Classical biological control for the protection of natural ecosystems. Biol Control 54:S2-S33

Waage JK (2001) Indirect ecological effects of biological control: the challenge and the opportunity. In: Wajnberg E, Scott JK, Quimby PC (eds) Evaluating indirect ecological effects of biological control. CABI Publishing, Wallingford, pp 1-12

Wajnberg E, Scott JK, Quimby PC (2001) Evaluating indirect ecological effects of biological control. CABI Publishing, Wallingford

Weed AS, Milan J, Schwarzländer M (2018) Analyses of nine years of citizen-based biological control monitoring of Dalmatian toadflax, Linaria dalmatica (Plantaginaceae) in Idaho, USA. BioControl. https://doi.org/10.1007/s10526017-9848-2

Winston RL, Schwarzländer M, Hinz HL, Day MD, Cock MJW, Julien MH (2014) Biological control of weeds: a world catalogue of agents and their target weeds, 5 th edn. USDA Forest Service, Forest Health Enterprise Technology Team, Morgantown. FHTET-2014-04. http://www. ibiocontrol.org/catalog/

M. Schwarzländer is professor of entomology at the University of Idaho and investigates biocontrol in the context of managing weeds of Eurasian origin in N. America. He was the chair of the symposium at the XXV International Congress of Entomology (Orlando, USA) at which the papers in this Special Issue were presented.

V. C. Moran was formerly professor of entomology at Rhodes University in South Africa. From 1986-1999 he was dean of the Faculty of Science at the University of Cape Town, where he is now an emeritus professor, and a member of the Weed Biological Control Research Group, continuing an abiding interest in this discipline that spans 50 years. He was a coorganizer of the ICE symposium.

S. Raghu is principal research scientist at CSIRO and works on the ecology and management of invasive weeds in Australia; he is Associate Editor for BioControl. 